\title{
Mark the Evangelist: His African memory
}

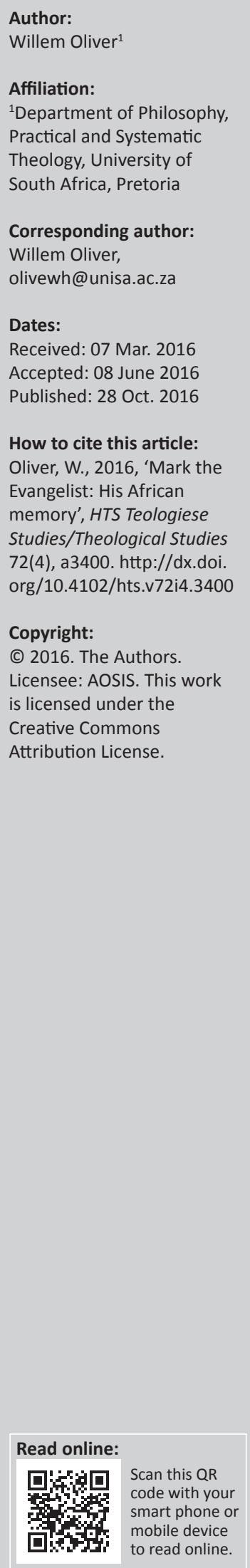

Mark is the author of the oldest gospel in the Christian Bible. Not much is known about him or his family except for a few references in the Bible. The general assumption, originating in the West, is that Mark was born and bred in Palestine. One of the main proponents of the Western view is Walter Bauer, a German theologian of the first half of the 20th century. His views rely heavily on the argument from silence, as Africa had - and to a great extent still has an oral culture. Contrary to the Western view, Thomas Oden, an American theologian, did research on the oral culture and investigated the African memory of Mark. This article presents a critical discussion and a review of the book written by Oden in 2011 titled The African memory of Mark. Oden seems to be very subjective in his remarks in favour of Africa, as is also clear from his book titled How Africa shaped the Christian mind, written in 2007, and the question is if he really has enough grounds for his postulations.

\section{Introduction}

Thomas Clark Oden is a distinguished world scholar with almost 200 publications to his name. ${ }^{1}$ In 2011 he wrote a second ground-breaking work in a series of three on the history of Africa, titled The African memory of Mark: Reassessing early church tradition. ${ }^{2}$ In this book he connects the history of Mark the Evangelist, the author of the Gospel according to Mark, to that of Africa.

The aim of his book is to present his readers (not really scholarly readers, but rather 'youthful Christian believers on the African continent'; Oden 2011a:14) with a re-evaluation of the person of Mark as well as the role he played in his time (cf. Smither 2012:92). In his book Oden continues to challenge Western scholars of the (late) 19th and 20th century who are discounting the African memory of Mark. This book is well structured and comprises of five parts:

- Part one: The African memory of St. Mark

- Part two: The identity of the Biblical Mark viewed from African tradition

- Part three: Mark in Africa

- Part four: Mark in the historical record

- Part five: The ubiquity of Mark.

These are complemented by a selected bibliography, as well as an author, subject and Scripture index. The writing style (with his readers in mind) is easy to follow.

In his book Oden (2011a:233) admits that for many years he defended/tolerated 'an overall accommodation to modern Euro-American academic culture'. The result was that he was overlooking the African memory of Mark. In his early years he was associated with the 'Bultmannians and form critics'. This came to an end in the 1970s (Oden 2011a:233), and more specifically in January 2003, when he visited the church of Augustine in Hippo, modern-day Algeria (Oden 2011a:234).

Oden's attempt to set forth the African memory of Mark is something that has not been done to the extent that he does it. As the scholars of the West are keen to keep Mark out of Alexandria, Oden makes it clear that there is ample evidence to the contrary. He explicates his task as follows (Oden 2011a):

My task is something like a trial lawyer defending an already convicted client he knows is innocent but who has remained imprisoned without a voice or remedy for decades. The condemned defendant in this case is the African memory of Mark, and more generally African Christianity in the early patristic period. I hope the jury [i.e., the reader; cf. Oden 2011a:222] is composed of fair-minded observers. (p. 216)

1.This includes more than 80 articles, more than 100 books, which he either wrote himself (or a chapter in the book) or of which he was the (general) editor.

2.The first book, published in 2007, is called How Africa shaped the Christian mind, while the third book has the title, Early Libyan Christianity, and was also published in 2011. 
In the last pages of chapter 11 (Oden 2011a:222-231) he delivers his 'closing argument ... like a defence attorney' in order to convince his reader about the story of Mark.

\section{The method}

Oden indicates that he has utilised the historical-critical method in reconstructing the traditional story (Oden 2011a:53). He does not elaborate much on it, but rather gives glimpses of how he went about gathering information. The important factor for him was to listen 'intently to the ancient story of the saint on its own merits' (Oden 2011a:54). Although he 'maintains respect for the Euro-American methodology' (Smither 2012:92), he adds that it is almost impossible for a Western scholar to make a mind shift from the empirical view (historical-critical method) to the traditional view (Oden 2011a:54). He himself, being a Western scholar, but focusing on Africa, could make that shift, because of his intellectual conviction based on a lifetime of study of early sources, as it is impossible to approach the ancient texts from a modern perspective (cf. Oden 2011a:59).

Oden admits that it is impossible to establish precisely when oral recollections became ancient documents. He calls it 'hubris' (Oden 2011a:54) when someone believes they can do this with high certainty - referring here to the transmission history of the synaxary ${ }^{3}$ narrative as well as the primitive oral transmission of all the New Testament narratives. Oden (2011a:54-55) rather relies on 'circumstantial evidence', indicating that the traditional narrative of Mark was passed along from generation to generation until it was written down during the 3rd century CE. Oden's research has brought him to the conclusion that 'Mark comes with impeccable credentials as an apostolic witness' (Oden 2011a:57). He characterises a witness as follows: 'A direct eyewitness to an unrepeatable event depends upon the Spirit to conserve and sustain the integrity and truthfulness of the previous eyewitnesses' (Oden 2011a:57). ${ }^{4} \mathrm{He}$ then adds something that is inconceivable to the modern mind and culture:

The task of the apostolic successor is not to improve upon the message or embellish it or add to it one's own spin, but rather simply to remember and attest it accurately, credibly and intelligently. (Oden 2011a:57)

Smither (2012:93) refers to Oden's methodology, which accommodates modern historiography and combines it with an African memory approach, as 'refreshing'.

\section{The African memory}

With the term African memory Oden refers to the ancient tradition about Mark in Africa (Oden 2011a:29). He is very

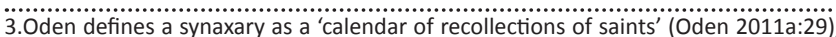
and as 'an account of a martyr or saint - to be read at an early morning service - or a compilation of such accounts organised according to days of recollection of the Christian year in the ancient African church tradition. These accounts are brie collections of the lives of saints for liturgical use in celebrations of saints in an annual cycle of memorials. They are similar to the Acta apostolorum apocrypha in Orthodox traditions' (Oden 2011a:61-62).

4.This is a universal truth. Yet the early witnesses were not so aware of the Holy Spirit. See heading below: 'My adumbrations'. adamant about the African memory of Mark: 'The only way to get inside the African memory of Mark is to allow it to tell the story of a saint. Otherwise the reader might mistake the saintly narrative intended for liturgical use as if it were a modern empirical historical description' (Oden 2011a:59). He is against a solely modern approach of the text: for him the African memory is a 'characteristic way of looking at history from within the special experience and outlook of the continent of Africa. Memory does not refer to contemporary memory alone, but to a two-thousand-year-long history of a way of remembering' (Oden 2011a:27).

The African memory has nothing to do with the West, but it depicts the way in which Africans 'historically viewed events and persons, and how they still characteristically remember them' (Oden 2011a:27). Oden (2011a:27-28) points out five characteristics for an event to belong to the African memory (naturally for him the story of Mark fits all these characteristics):

- The event has been commonly remembered on the continent of Africa.

- The event is remembered in the same or very similar ways.

- Consent to the event is unenforceable.

- The event has been remembered over many generations of Africans.

- The narratives of the event have been told in many of the indigenous languages of the African continent.

While it takes space as well as time to make a memory, the African memory must appear in a succession of revered sacred and secular texts that spans over many centuries, cultures and languages. If one wants to understand continent-wide African Christianity, one will have to do it 'through this textual history that begins with Mark' (Oden 2011a:28).

Oden (2011a:35) honours modern scholars such as Colin Roberts who in his lectures, published as Manuscript, society, and belief in early Christian Egypt (1979), acted as a decisive turning point in the research of the African memory. In his book Roberts depicts how the earliest forms of paleoChristianity in Egypt were developed out of the Jews in Alexandria who were the largest Jewish community in the Diaspora (Oden 2011a:35). Today quite a few scholars share Oden's point of view, such as Pearson (1986a, 1986b, 1990, 1991, 1997, 2004), Robinson (1996), Bagnall $(1993,2001)$ and many others (cf. Oden 2011a:35).

\section{Sources referring to Mark}

The classic texts referring to Mark, which Oden used, will be discussed briefly.

\section{Coptic liturgy (especially in its synaxaries)}

The synaxaries always give Mark the foremost place among apostolic figures in Africa (Oden 2011a:61; cf. also Oden 2011a:33). 


\section{The Martyrium Marci (Martyrdom of Mark)}

The Martyrium Marci, of Egyptian provenance, an anonymous primitive Urtext dating from the 3rd century (Oden 2011a:28), forms part of the Patrologia Graeca (specifically PG 115, cols 167-170; cf. Oden 2011a:169). It dates back to the 2nd or 4th century CE, 'recalling early written forms of documentation, carefully guarded and passed on through sacred tradition' (Oden 2011a:64), and is a conflation of previous traditions that related to Mark's martyrdom during the 1st century (Oden 2011a:65).

\section{Sawirus (Severus) ibn al-Muqaffa, Bishop of al-Ashmunein}

Being one of the most important sources for the Coptic memory of Mark (for both the Coptic and Egyptian history), Sawirus was the 'scholar-bishop of al-Ashmunein' (Oden 2011a:66), who wrote between 955 and 987. He is traditionally celebrated as being the author of the classic History of the Patriarchs of the Coptic Church in Alexandria (HP) (Oden 2011a:66). Making use of Eusebius of Caesarea's Historia Ecclesiastica (Hist. Eccl.) and the writings of Cyril the Great, he wrote a lengthy chronicle on the history of 'Saint Mark, the Disciple and Evangelist, Archbishop of the great city of Alexandria, and first of its Bishops' in his HP 135 (cf. Oden 2011a:67; cf. also Oden 2011a:33).

\section{Shenouda III (Pope of Alexandria)}

Shenouda III was Pope of Alexandria and Patriarch of the See of St. Mark in 2011 when Oden wrote the book, but he died in the following year. Pope Shenouda III had the most complete collection of the traditional narrative and he combined it into a synoptic view of 'all the ancient and modern sources on Mark that correspond to Coptic Orthodoxy' (Oden 2011a:75; cf. also Oden 2011a:33).

\section{Eusebius}

Eusebius of Caesarea, a Roman historian referred to as the 'first church historian' and also as the 'father of Church History' (Doergen 1937:446-448; cf. Verdoner 2014:239) wrote a ten-volume work called Historia Ecclesiastica in the 4th century - between 300 and 325 CE. In his Historia Ecclesiastica 2.16.1 (cf. also 2.24) he stated: 'They say that this Mark was the first to have set out to Egypt to preach the gospel.' According to the oral culture, Mark therefore was the first to preach the gospel in Alexandria, containing the words of the Gospel he had already written himself (in Rome). He received this information from the 'they' which were, according to Oden (2011a:209-210) the 'earliest presbyters' who were John the Elder (distinguished from John who also wrote a Gospel), Aristion and Polycarp. With this work Eusebius continued the 'steadily received traditions' (Oden 2011a:209) that were reported by Papias, the bishop of Hieropolis, an apostolic father who lived circa 70-163 CE. Eusebius had at his disposal an 'unsurpassed personal library of early Christian primary sources in Caesarea' (Oden 2011a:211). He inherited most of his documents from Origen, who had his own distinguished library, as well as from Pamphilus. In fact, he had one of the best libraries in the Near East, supplemented by libraries in Jerusalem and Antioch.

\section{(Pseudo-)Clement's letter to Theodore}

Oden (2011a:198-199) concludes, against the bulk of scholars (like Jay 2008:573-597; Watson 2010:128-170; Carlson 2005, and many others) and myself, that Clement wrote this letter (cf. also Brown 2008:535-572; Viklund \& Paananen 2013:235247). Nonetheless, the letter contains very valuable information about Mark. Folio I (Recto 15-25) states:

As for Mark, then, during Peter's stay in Rome he wrote an account of the Lord's doings, not, however, declaring all of them, not yet hinting at the secret ones, but selecting what he thought most useful for increasing the faith of those who were being instructed. But when Peter died a martyr, Mark came over to Alexandria, bringing both his own notes and those of Peter, from which he transferred to his former books the things suitable in whatever makes for progress toward knowledge. Thus he composed a more spiritual Gospel for the use of those who were being perfected. (cf. Oden 2011a:201-202)

Oden elaborated much on the last part of the quote referring to the secret gospel of Mark (Oden 2011a:205-207) and concluded that in the end there were three versions of Mark: A canonical Mark, a spiritual Mark, and a Carpocratian distortion of the spiritual Mark (Oden 2011a:207).

\section{Other classic texts and evidence about Mark}

Oden also mentions other classic writers that refer to Mark, namely Clement of Alexandria, Origen, Athanasius, Cyril, Jerome and John Chrysostom (Oden 2011a:28, 33). As will be seen in the discussions below, a few texts of the New Testament, especially Acts, also refer to Mark, as well as an abundance of secondary African literature on Mark (cf. Oden 2011a:28).

\section{An exposition of the life of Mark}

Under this heading the life of Mark will be discussed as described by Oden. The mass of information in Oden's book is structured under self-chosen headings, starting with the birth of Mark up to his martyrdom, and ending with an evaluation.

\section{Cyrene}

During the time of the Maccabees, the Jews in Palestine endured harsh wars, population displacement and foreign occupation (Oden 2011a:18), taking place between the 3rd century BCE and the 1st century CE, more specifically 200 BCE-120 CE (Oden 2011a:18, 19). The two cities of refuge where the Diaspora Jewish population was relocated (Oden 2011a:20) were Cyrene and Alexandria - the most crosscultural cities on the continent (Oden 2011a:18).

The Diaspora Jews remained religiously observant Jews, faithful to the Mosaic Covenant, and visited Jerusalem 
annually in line with the Covenant (Oden 2011a:18). Their religious leaders were called Levites, who were well learned in the Hebrew Scriptures (Oden 2011a:18). They were actively messianic $^{5}$ in their hopes and historical perspective (Oden 2011a:19). The language spoken in Cyrene was Greek, even six centuries before Mark was born (Oden 2011a:19). They also spoke Roman, Punic, Berber and Nilotic (Oden 2011a:20).

John Mark was most likely born close to Cyrene which is in the region of Cyrenaica (sometimes identified as Ptolemais or Barku) in North Africa between 5 and 15 CE (Oden 2011a:21, 45). His birth place could also be Ebryatolis ('city of Jews'), a settlement of Jews on the outskirts of Cyrene (Oden 2011a:46). Oden (2011a:44) acknowledges the fact that evidence of Mark's birth is 'inferential and circumstantial', but then adds that it is not easily dismissed. His name, John Mark, was multicultural: John was Hebrew and Mark was Latin (Oden 2011a:21). His family most probably first called him Mark after they emigrated to Jerusalem (Oden 2011a:80).

Cyrene was an inland city in Africa - not like Alexandria or Carthage (Oden 2011a:18). It was located upland in the mountains (Oden 2011a:19) with Apollonia as the nearest port (Oden 2011a:19). Its surrounding territory was Cyrenaica, the northernmost part of the continent, modern-day Libya (Oden 2011a:19). This was an international trading city as they traded in the therapeutic and mysterious medicine called Silphium (Oden 2011a:19). Like Alexandria it became an African asylum city accessible to refugees who fled from other countries. During the 1st century it had a sizable Jewish population (Oden 2011a:18-19).

Oden (2011a:44) identified four ironies regarding Mark's birth:

- His birth took place in the most remote of the three known continents - most out of the way.

- His family fled from this most remote place to the 'vortex of Hebraic culture' - Jerusalem.

- As a young man he came from nowhere and became known as the apostle to everywhere.

- During his lifetime he had travelled the eastern Mediterranean upon which he returned to Africa's greatest city, Alexandria, and brought with him the Gospel of Mark - the 'embryonic form of early Christian catechesis'.

Oden (2011a:46) pictures Mark's family as Diaspora Jews belonging to a Diaspora economy, wealthy cultivators and traders, and learned in the Hebrew Scriptures. According to Sawirus (HP 135-136), there were two brothers living in one of the cities of Pentapolis in Libya (which were the five Western cities or the five cities of African Cyrenaica; cf. Oden 2011a:47) in the West, called Cyrene. They were from the Israelite tribe of Levi (Ac 4:36; Oden 2011a:21, 48). The older brother was Aristopulos (Aristopolis or Aristobolus or Aristobulus or Aristo-Paulus; cf. Oden 2011a:21; cf. also Sawirus HP 135-137) and the younger one was Barnabas 5.Oden (2011a:20) defines 'messianic' as the expectation of the coming Messiah to fulfil the purpose of God in history. (his name was actually Joseph; cf. Ac 4:36-37). Sawirus (HP 135-137) said that there were two brothers and a cousin, Strapola (Oden 2011a:82), who became the wife of Peter (the chief of the apostles; cf. Oden 2011a:48). The family lived 'together with Mark's mother and her brother Barnabas' (cf. Sawirus HP 135-137), which 'might explain the close intimacy between Mark and Barnabas' (Oden 2011a:82). The name of Mark's mother was Mary (Oden 2011a:21; cf. Sawirus HP 135-137). Here we find a problem concerning Barnabas: it is not clear whether he was the brother of Aristopulos or of Mary. Mark could therefore be the cousin or nephew of Barnabas. Oden (2011a:86) also applied this to Mary: she could be Barnabas' sister or cousin or sister-inlaw. In Colossians 4:10 Paul refers to Mark as the cousin of Barnabas (cf. Oden 2011a:85). ${ }^{6}$

They were rich farmers who produced agricultural products which they marketed internationally (Oden 2011a:46). They were also well-travelled (Oden 2011a:47-48). They were proficient in sea commerce and the pertinent international languages (Greek, Latin, Aramaic) (Oden 2011a:47). They were pious Jews who memorised the Scriptures (Oden 2011a:46) and therefore understood the Law of Moses and knew by heart many books now belonging to the Old Testament. They went several times per year to Jerusalem for seasonal feasts (Oden 2011a:21), because in key times of seasonal celebration, such as Passover and Pentecost, these pious and observant Jews preferred to be in Jerusalem (Oden 2011a:51).

Mark was educated in the Greek and Hebrew cultures by his family. He could speak multiple languages (Shenouda III 1995:9) due to his good education. He was able to explain Jewish customs and translate Semitic terms to a Greek and Latin audience (Oden 2011a:49). The languages Mark would have known from birth or acquired were Aramaic, Greek, Latin, a Libyan language and Hebrew (Oden 2011a:49).

Just before New Testament times, around 5-20 CE, there were tribal conflicts and civil disturbances or disorder ('encroaching marauders' - Oden 2011a:22) in Cyrenaica (Oden 2011a:20, 21,36). In Cyrene, during the early 1st century - in the time of Augustus Caesar - some Berber and Ethiopian tribes robbed the family of all their wealth. These Levitical Diaspora Jews, including John Mark's family (Oden 2011a:49), then fled to the land of the Jews (Oden 2011a:20, 45, 48), specifically to Jerusalem (Oden 2011a:46). According to Acts 12 they settled somewhere near Jerusalem after their transition (Oden 2011a:46, 48). This included Barnabas (Oden 2011a:48-49).

\section{Jerusalem}

Mark, the child of Africa, further grew up in Jerusalem and increased in stature by the grace of the Spirit (Oden 2011a:48). His mother's house was on Zion Hill (Oden 2011a:48), which could be a place they moved to from outside Jerusalem, but which is not indicated by Oden. There Mark and his mother, which he indicates that Barnabas could be Mark's cousin or uncle. 
Mary, became involved with the Jesus movement (Oden 2011a:21). They formed part of the core circle of Jesus in Jerusalem (Oden 2011a:51) - a culture-transforming movement in this city (Oden 2011a:22). Mary was chosen by Jesus to offer hospitality to the earliest disciples (Oden 2011a:22). According to Luke 8:2-3, and other traditional sources, Mary was part of the women who supported Jesus with their possessions and resources (Oden 2011a:95). As a variety of Scriptures (Mk. 14:14-15; Ac. 1:13-14; 12:12) refer to Mary and her young son who resided in Jerusalem, the implication is that his father had died in the meantime (Oden 2011a:51).

Since the family of Mark was wealthy (Ac. 1:13; 12:12-13; cf. Oden 2011a:49) and had Levitical connections, it would make sense that their house was located in the city near Zion where many priests lived (Oden 2011a:97). With an upper room added (Mk. 14:15; Ac. 1:13; cf. Oden 2011a:22, 51), Mary's house was large enough (Ac. 12:12) to accommodate servants on a premises where the servant (Rhoda) had to walk to the gate, which was a distance from the house (cf. Ac. 12:13). It was also spacious enough to take care of more than a dozen guests (Oden 2011a:96). This house served as a safe place where the key leadership of the apostles could gather during the times of persecution (Oden 2011a:96). Oden ascribes at least four major events that took place in Jerusalem at the house of Mary: the Lord's Supper, ${ }^{7}$ the Lord washing the feet of his disciples, the outpouring of the Holy Spirit at Pentecost and the flight of Peter to this house after his imprisonment (Peter sought refuge from Herod in the house of Mary [Ac. 12:12; cf. Oden 2011a:86]; Oden 2011a:94). After the resurrection of Jesus, the disciples were again in this house (Ac 1:13) where they continued to meet for Pentecost and for continuous prayer (Oden 2011a:103-104).

According to the Coptic synaxarion (Synaxarion: Month of Baramouda [=Ethiopic-Amharic Miyazia] 30; Oden 2011a:94) this house was the first Christian church (the first house church; cf. Oden 2011a:103), where they ate the Passover, where they hid after the death of Jesus, and where in its upper room the Holy Spirit came upon them. The correlation of these events is dependent upon the exegesis of Mark 14 in conjunction with Acts 1-2 and 12. The house of Mary therefore became the first church in the world (Oden 2011a:98). This was celebrated very early by both the Jerusalem community of faith and the African tradition (Oden 2011a:98). This was the first great gift of Africa to Jesus' ministry: the providing of a house and a space of hospitality in which to gather and pray (Oden 2011a:98). 'Upper room language' is found in Mark 14:15, Luke 22:12 and Acts 1:13 (cf. Oden 2011a:105-106). Luke 22:12 called it a 'large room upstairs - all furnished' (cf. Oden 2011a:106). The probability that there would be references to different upper rooms in these texts is small, according to Oden; therefore, all these references are to the same room (Oden 2011a:106). The only problem is that the upper room in Mark 14:15 and Luke 22:12 is called anagaion, while in Acts 1:13 it is called hyperoon
(Oden 2011a:106). There is no hint between Acts 1:13 and 2:1 that they changed locations (Oden 2011a:107). The upper room was in Mark's house and there the Holy Spirit descended on them (Oden 2011a:107). This leads Oden (2011a:107) to conclude: 'And if this is so, then the African component of the earliest layers of Christian memory of the gifts of Pentecost cannot be dismissed', and 'the upper room remained the center of mission and apostolic activity from Pentecost to Peter's flight from prison'. In Acts 2:1-2 the 'one place' could then only refer to the upper room (Oden 2011a:107-108).

When Jesus and his disciples walked from the house to Gethsemane, Mark and his mother most probably joined them (Oden 2011a:104). When the disciples returned from the Mount of Olives to Jerusalem, they went to this house (Ac. 1:13; cf. Oden 2011a:105). Therefore, before and after the resurrection, the disciples (most probably) stayed at this house (Lk. 22:12; cf. also Oden 2011a:105). They awaited, on the instruction of the Lord, the outpouring of the Holy Spirit (Oden 2011a:105). Believers from Libya were present at Pentecost in Jerusalem. Shenouda III (ch. 5 n. 4) said:

These cities [the five of the Pentapolis of Libya] were represented at the time the disciples received the Holy Spirit on the Pentecost, '[a]nd the parts of Libya about Cyrene'. (cf. Oden 2011a:108)

The Acts narrative (Ac. 2) also states that among the people who were at the outpouring of the Holy Spirit were those 'from Libya in the area of Cyrene' and from Egypt (cf. Oden 2011a:108). Oden (2011a:109) remarks: 'Even today, the vast African body of believers is still marveling at the Pentecost event, hosted by an African woman.'

Shenouda III (1995:119), in quoting the Syriac Orthodox Patriarch Mar Aghnatius Yacoub, states that Mary's house was everything that has been said above plus: 'Later the house was consecrated to be a church with the name of Mother of God ... It became the seat of Jerusalem. St. James, [sic] became the first Bishop of Jerusalem, and stayed there' (cf. Oden 2011a:98). The house was largely (not completely) wrecked in 1009, but renovated by the Syrians from 1855 to 1880 (Oden 2011a:99). The specific location of the house is known today 'with some reasonable probability' (Oden 2011a:96). Already by the 3rd or 4th century it was identified as Mary's house with epigraphic evidence from the 6th century (Oden 2011a:96). The remnants of this 1st-century house, partly hidden, partly exposed, are in the upper city on the south-western heights of Zion Hill. There we find St. Mark Monastery on the ancient site of the house of Mark the Evangelist, according to a 6th-century inscription which was discovered in 1940 (Oden 2011a:98). The place is today often called the Monastery of St. Mark or The house of Mary, mother of Mark (Oden 2011a:99). Within this monastery are a Byzantine church and the offices of the patriarch (Oden 2011a:99). The house is still regarded as the first baptismal place, and the 'Seat of St. James the apostle, the first bishop of Jerusalem' (History of Jerusalem n.d.:4; cf. Oden 2011a:99). 
The church of the first four centuries (33-333) had remembered this hallowed location explicitly, due to its liturgical significance, its relation to the Eucharist and Pentecost, and to Mark's Gospel (Oden 2011a:99). According to Oden (2011a:99), this house was referred to as a site of pilgrimage by:

- the Bordeaux Pilgrim (Itinerarium Burdigalense) in 333

- Cyril of Jerusalem in 348

- the Spanish nun Egeria in 385.

In the 6th century a church (a very ancient basilica) was built at this site of which a portion of one wall still remains, with the inscription:

This is the house of Mary, mother of John, called Mark; Proclaimed a church by the holy apostles under the name of the Virgin Mary, mother of God, after the ascension of our Lord Jesus Christ into heaven; Renewed after the destruction of Jerusalem by Titus in the year A.D. 73. (cf. Oden 2011a:100)

This house is therefore authenticated by epigraphic, literary and archaeological sources in combination (Oden 2011a:100).

\section{Mark's (and his father's) conversion}

According to the traditional narrative, the young Mark came under the tutelage of Peter of Capernaum (Simon Peter) who was the son of Jonah (Mt. 16:17; cf. Oden 2011a:79, 80). Mark learned the Christian doctrines from him out of the Holy Scriptures (Oden 2011a:48). Peter was married to Strapola, who was a relative of Mark's father (Girgis 2002:27; cf. Oden 2011a:82), the cousin of Aristopulos (Oden 2011a:80). Peter first led him to Christian teaching and discipleship (Oden 2011a:80). As Mark visited Peter's house often, he learned the Christian teachings (Synaxarion: Baramouda [EthiopicAmharic Miyazia] 30; Oden 2011a:80).

It is unknown when Mark was converted. According to the African memory, it could have taken place during one of his visits to Peter in Capernaum, when the disciples had the last supper in his mother's house, or during Pentecost and the birth of the church (Oden 2011a:86). It could be that after Pentecost, when Peter called on the people to repent and be baptised, Mark himself was baptised (Oden 2011a:110-111). It could be that in 1 Peter 5:13, where Peter referred to 'my son Mark' that he referred to Mark whom he baptised (Oden 2011a:111). It can be stated that by the time of the first missionaries Mark was already known and trusted by the apostles and therefore already converted (Oden 2011a:86).

According to the Synaxarion (Baramouda [Ethiopic-Amharic Miyazia] 30; cf. Oden 2011a:80, 86), the symbol of the lion (prominent in pictures with Mark) is linked to the conversion of Mark's father. Father and son were walking along the Jordan River in a wilderness area when two lions attacked them. The father cried out to his son to escape to save himself. However, Mark answered: 'Christ, in whose hands our lives are committed, will not let them prey on us.' Mark then prayed to 'Christ, Son of God' for protection. The lions were rendered harmless. Afterwards Mark's father was converted and baptised by his son. Although Westerners discount this story from Africa, and post-Enlightenment observers tend to easily dismiss it as just a story (Oden 2011a:80), Oden sees it as not just the only glimpse we have into Mark's youth, but also 'the pivotal first step in the African narrative'. This episode gave rise to a major symbol that has infiltrated the iconic memory of Mark for all the centuries to come: the lion. The lion was the symbol of Mark's youthful faith in the fulfilment of God's promises to Israel through his Son, Jesus Christ. ${ }^{8}$

\section{The Gospel according to Mark}

Oden (2011a:193-194) discusses Mark's stay in Rome with Paul and Peter. He refers to Clement of Alexandria (who gave the best early literary evidence of Mark in Alexandria) and specifically to his Hypotyposeis 8 (quoted in Hist. Eccl. 2.16.1), stating the following:

- Mark was in Rome with Peter, as viewed by the Alexandrian Christians.

- Mark wrote his Gospel in Rome in response to a request which came from the laity of Rome.

- Mark had followed Peter for a long time.

- Peter's virtual son, Mark, was providing assistance to him under conditions of threat; the threat was imprisonment in Palestine; this is the reason why Peter went so far away from Palestine.

- Mark wrote what Peter had preached.

From Clement's Adumbrations (on 1 Pt. 5:13) the following becomes clear (cf. Oden 2011a:195-196):

- Mark was physically with Peter in Rome.

- Mark heard Peter preach in front of high Roman military officials.

- They were so impressed with Peter that they requested Mark to write it down.

- Mark wrote his Gospel on the things that Peter was preaching.

- This became his Gospel.

Mark was the first to write down the Good News, which constituted the beginning of Christianity (Oden 2011a:22). His Gospel very quickly and widely circulated and became influential and the pattern for all subsequent reports of the history of Jesus (Hurtado 2004:132). He was also the first person sent by Jesus' followers to teach the gospel on the African continent (Oden 2011a:22). According to Paananen (2012:89) who quoted Pseudo-Clement:

Clement affirms that in Alexandria Mark the evangelist expanded the Gospel that he had written in Rome ${ }^{9}$ during Peter's

8.According to O'Neill (n.d.), the lion is the symbol of Saint Mark, who is the patron saint of Venice. Venetian tradition has it that Mark was travelling through Europe when he arrived at a lagoon in Venice. There an angel appeared to him, saying, 'Pax tibi Marce, evangelista meus. Hic requiescet corpus tuum' (May Peace be with you, Mark my evangelist. Here your body will rest). In 828 Rustico da Torcello and Bon da Mark my evangelist. Here your body will rest). In 828 Rustico da Torcello and Bon da Malamocco used this tradition as justification for stealing the remains of Mark from eventually buried where they were interred in the Basilica of St. Mark.

9.This is against scholars like Koester (1983:35-57; 1989:19-37; 1990:275-286, $293-$ 9.This is against scholars like Koester (1983:35-57; 1989:19-37; 1990:275-286, 293-
303), Schenke (1984:65-82) and Crossan (1985:91-121; 1988:283-284; 1990:155168; 1991:328-323, 411-416, 429-430) who argue that the expanded version of $168 ; 1991: 328-323,411-416,429-430)$ who argue th
Mark represented an earlier form of the Markan text. 


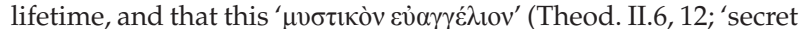
Gospel' in Smith's translation) was still in use in Alexandria. ${ }^{10}$

According to Oden (2011a:83), there are two references to Mark in his own Gospel:

- Mark 14:51: Mark is seen as the young man who was present at the capturing of Jesus and who fled naked leaving his garment behind (cf. Oden 2011a:83). As the other Gospels did not mention this young man, Mark remembered his own actions. According to Oden, this is characteristic of Mark's style: self-effacing and penitent. His nakedness symbolises his loss of defences and his shame at fleeing.

- Mark 16:5-7: On the third day after Jesus' death and burial, an anonymous young man appeared after Jesus' resurrection and he spoke to the women. According to African memory this could be Mark, although other Gospels held that it was an angel (Mt. 28:5-7).

\section{Mark's (missionary) journeys}

The ancient tradition and African memory do not agree much on the time and place of Mark's journeys. Oden, however, does not see this as a problem and presents the different accounts while telling where Mark travelled. According to ancient tradition Mark journeyed much during his lifetime and preached on all the continents belonging to the Roman Empire: Africa, Europe and Asia (Oden 2011a:11). This is the reason why ancient tradition called Mark the universal apostle (Oden 2011a:53). Oden (2011a:52) states that Mark travelled more widely than Paul. Mark journeyed from 33-68 CE, thus for 35 years (Oden 2011a:128). According to the African memory, he was at the sides of Paul and Barnabas (Oden 2011a:49) during the events of Acts 5-12 preceding Paul's first missionary journey (Oden 2011a:112). According to the official Coptic narrative of Pope Shenouda (Shenouda III 1995:20), 'St. Mark preached in Judea, Lebanon, Syria, Antioch and in Cyprus. He reached Paphos, Pamphylia, Rome, Colossi, Venice and Aquila' (cf. Oden 2011a:112). The synaxaries (Coptic Synaxarion for Barbmouda [EthiopicAmharic Miyazia] 30) also indicate that Mark travelled a lot:

After the ascension ... [Mark] accompanied Paul and Barnabas to preach the Gospel in Antioch, Seleucia, Cyprus, Salamis, and Perga Pamphylia where he left them and returned to Jerusalem. After the Apostolic Council in Jerusalem, he went with Barnabas to Cyprus. After the departure of Barnabas, with the order of the Lord Christ, St. Mark went to Afrikia, Berka [Barka], and the Five Western cities. He preached the Gospel in these parts, and they believed. He laid his hands on most of its people. From there, he went to Alexandria in the first of Bashans 61 A.D. (cf. Oden 2011a:60)

Several times in his book Oden takes the Bible to report about the journeys of Mark and also provide a sort of an itinerary for him, to prove that Mark was at the centre when world mission had begun (cf. Oden 2011a:122-123; 126-128; 219-220):

10.This is against scholars like Theissen and Merz (1996:24-27) who are of the conviction that the Gospel was written in Syria, and Schröter (2010:278) who argues that is was written in Palestine.
- Acts 11:25-26: Barnabas in Antioch with Saul (Mark could be there).

- Acts 11:27-29: Mark most probably went with Barnabas to Jerusalem to offer relief during famine.

- Acts 12:12: Mark was with the disciples from the beginning in Jerusalem.

- Acts 12:25-13:5: He was in Antioch with the earliest Christian leaders and prophets.

- Acts 12:25: After Saul/Paul and Barnabas have delivered the money to the poor in Jerusalem, they returned to Antioch, taking Mark with them (cf. also Oden 2011a:114).

- Acts 13:4-13 and 14: Mark went with Barnabas to Cyprus and Perga (now Turkey).

- Acts 13:13: Mark left Barnabas and Saul in Perga and returned to Jerusalem in $45 \mathrm{CE}$ before the Council (cf. Oden 2011a:45, 127-128). After that, Mark most probably went to Colossae (Girgis 2002:89; cf. Oden 2011a:128).

- Acts 15:37-39: He was with Barnabas when they received funds for the earliest Christian mission.

- Acts 15:39: Mark and Barnabas left Paul and went to Cyprus (cf. Oden 2011a:212).

- Colossians 4:10 and Philemon 24: After the breach between Mark and Paul during Paul's first two missionary journeys, we find it healed in these verses.

- 1 Peter 5:13: Peter refers to Mark as 'my son'. Because Peter's letter was addressed to various churches in Asia Minor, Oden concludes not very convincingly that these churches must have known Mark.

- 2 Timothy 4:11: In the face of death, Paul asked Timothy to bring Mark to him, adding that 'he is profitable to me for the ministry'. Should Mark have gone to Rome, he would be at the martyrdom of both Paul and Peter. Both Roman and African memory are concurring to this 'fact' (cf. Oden 2011a:220).

Sawirus (HP 140) related that Mark had, before this, already been doing missionary work in Libya (cf. Oden 2011a:126). Added to this, Acts 9:32 states that Peter was on his early mission in the region surrounding Jerusalem. According to Oden (2011a:127), Mark most probably accompanied him. This would be in line with Sawirus (HP 140), stating that Mark did missionary work with Peter in Bethany. After an angel appeared in a dream to Peter, telling him to go to Alexandria and Rome, he and Mark split up and Mark went to Alexandria (Sawirus HP 141; cf. Oden 2011a:133, 142). However, according to Sawirus (HP 140), the split was not immediate: 'Peter and Mark went to the region of Rome, and preached there the word of God. And in the fifteenth year after the ascension of Christ, the holy Peter sent Saint Mark, the father and evangelist, to the city of Alexandria, to announce the good tidings there' (cf. Oden 2011a:137).

According to the Coptic chronology, Mark joined Peter's mission by the early 40s and returned to Libya and Egypt in the 40 s or 50 s till his death in the 60s. The chronology specified that he was back in Africa (Libya or Alexandria) in 43 till his death in 68 (cf. Oden 2011a:36). Early Christian traditions place Mark back in Africa as early as the first years of 
Claudius (41-44) or as late as the reign of Nero (54-68; cf. Hist. Eccl. 2.24; Oden 2011a:36). Eusebius was the first to provide a specific date for Mark's arrival in Alexandria: In the third year of the reign of Claudius the Emperor, that would be in 43 CE (Oden 2011a:212). Encyclopedia Coptica (2006) also states that Mark was (according to traditional Coptic sources) in Egypt during the reign of Nero. Oden (2011a:215) indicates that 'official Coptic history' places Mark in Egypt in 'the 15th year after the ascension of Christ', which Oden sets on $45 \mathrm{CE}$, maybe just before the Council in Jerusalem, but he does not concur with it: he indicates that Mark was with Peter and Paul in Rome and also at the Council of Jerusalem in 49, which means that he would only be back in Africa after the martyrdom of Paul and Peter in 64-68 (Oden 2011a:36).

According to Clement, Mark was with Peter when the latter wrote his first letter 'in Babylon'. Oden (2011a:196) poses the question: Does 'Babylon' refer to Rome or to Babylon of Egypt ('old Cairo'; Oden 2011a:114)? This could well be Babylon of Egypt, where many refugees gathered at a crucial military and trade location (cf. Oden 2011a:194). As he could not find any firm indicators on this, he utilised Acts 12:17 where Peter came to the house of Mary to pick Mark up and went away to 'another place', taking Mark (his confidant and most probably a participant of all the events preceding Acts 12) with (Ac. 12:17; cf. Oden 2011a:114). According to Oden (2011a:115) there are three reasons why they could have fled to old Cairo:

1. Mark knew Africa well, and Cairo was a safe place (refugee centre) for refugees.

2. As Mark was, according to African memory, a close relative of Peter, he was responsible for his safety.

3. Mark would have the means and know-how to get Peter out of Jerusalem to Cairo.

Interestingly, in 1 Peter 5:13 Peter referred to Babylon and to Mark in the same verse (cf. Oden 2011a:120).

Oden summarised Mark's main journeys as follows: Cyrene to Jerusalem to Rome to Cyrene and Egypt where he was martyred in Alexandria (Oden 2011a:21-22).

\section{Mark in Alexandria}

After his missionary journeys with Paul and Peter, Mark returned to Africa at a date not known precisely. He did not go directly to Alexandria, but first went to the Pentapolis. Mark thus went from Rome to his own messianic Jewish people in Libya to be the first apostolically sent missionary to Africa (cf. Oden 2011a:215). His ministry in Cyrene was blessed with signs and wonders (Martyrium Marci 1-2; cf. Oden 2011a:138). This was an indication that African Christianity did not begin in Egypt, but in the unlikely region of Libya (Oden 2011a:139, 140). The Egyptian historian, Aziz Atiya (1968:433) wrote:

Indeed, the apostle of Egypt was a native Jew of Cyrene, St. Mark the evangelist, who came to Alexandria by way of the Pentapolis, and after planting the new faith in Egypt, himself returned to Cyrene to work with his fellow citizens on more than one occasion. (cf. Oden 2011a:212)

Oden (2011a:213) concurs with MacRory (1910) who came to the conclusion that Mark could have been in Alexandria between 50 and $60 \mathrm{CE}$, because during that time the New Testament is silent with regard to Mark (Oden 2011a:213). However, on the word of Koester (2000:104), Oden also states that Mark could probably be in Ephesus in 54-55 (Oden 2011a:220).

Mark was the first one who 'fed the flock of Christ' in Africa and his pattern was followed 'generation after generation' (Sawirus HP 109; cf. Oden 2011a:73). He did not only preach in Alexandria, but also founded churches in the region. In Alexandria Mark's vocation was (based on the words of the prophet Isaiah - the same words his Gospel starts with) 'to receive the gift of the Spirit to help make the road smooth in all of the African continent for proclaiming the good news' (cf. Oden 2011a:141). The Spirit prompted Mark to first go to Pharos, which was the lighthouse in Alexandria (Martyrium Marci 2; cf. Oden 2011a:141). He entered the city at the Mendion Gate (Oden 2011a:142, 143) or at Bennidion (Oden 2011a:143-144). The Spirit made his entry easy during his first moments in Alexandria when he met with Anianus/ Anianos (Oden 2011a:143). (Oden [2011a:143] uses three sources for this story.) When his shoe strap broke, he thought: 'Now I know that the Lord has made my way easy' (Sawirus HP 142). He went to Anianus the cobbler who accidentally cut his finger (pierced his hand) with an awl and cried out: 'God is One!' (Sawirus HP 142; Martyrium Marci 3). Out of this simple exclamation, Oden remarks, emerged the long history of Christianity in Africa (Oden 2011a:144, 145). Mark spat on the ground, made clay and applied it to the wound, saying: 'In the Name of the Father and the Son and the Holy Spirit, the One and living eternal God, may the hand of the man be healed at this moment, that thy holy Name may be glorified.' The wound was healed at once (Oden 2011a:144). According to Sawirus (HP 143) Anianus then admitted that they (the believers in Alexandria) mentioned God with their mouths, but they did not know who he was (Oden 2011a:145).

Mark went with Anianus to his house and told him he did the miracle in the Name of Jesus Christ (cf. Oden 2011a:146) and then proceeded from proclaiming the gospel to teaching catechetics (Sawirus HP 143-144; cf. Oden 2011a:147). Mark told him about the fulfilment of the promises in the Hebrew Scriptures, but according to Sawirus HP 144, Anianus said he had never heard of all these books (this is an interesting observation, as Oden says that the Jews in Alexandria were messianic Jews!) (Oden 2011a:148). Mark baptised Anianus, as well as all the people of his house and all his neighbours (Sawirus HP 144; cf. also Martyrium Marci 4; Oden 2011a:148). Anianus became Mark's helper and preached himself (Sawirus HP 144-145; Oden 2011a:148). They challenged the idolatry in the city (Oden 2011a:149). 
As Alexandria was the most influential centre of the whole Mediterranean world during that time, the first Christian school, a catechetical school was founded there (Oden 2011a:22). Oden is not explicit on who the founder was, but stated later (Oden 2011a:245) that Mark is popularly remembered as honorary founder of the School, though Pantaenus is 'traditionally regarded as the earliest head' (Oden 2011a:243).

When there was an outrage in the city, Mark appointed Anianus as his successor bishop, plus three priests and seven deacons (Sawirus HP 144-145; cf. Oden 2011a:149). He then went to Pentapolis in Libya for two years, where he preached to the Libyan church, specifically in the region from Barka in the Pentapolis to Kairouan in Tunisia. He also appointed successors there. When he returned to Alexandria, he found the church in Alexandria flourishing (Oden 2011a:150). The believers had built a church near the sea called the Cattlepasture (ta Boukolou; Oden 2011a:151).

According to the tradition, Mark was chosen to bring the gospel to Africa. This tradition includes the earliest traditions from the Eastern Church, the Western Church as well as the proto-Coptic Egyptian-Libyan tradition (cf. Oden 2011a:222). At the Feast of St. Mark Troparion they honour Mark for freeing Egypt from deception (Oden 2011a:246). Oden interprets that deception to be the 'illusions of the goodness of idolatry' (Oden 2011a:246). Referring to Hanna (1875) Oden (2011a) indicates that:

\begin{abstract}
the Divine Liturgy of St. Mark remains even today at the heart of historic African spirituality ... Mark composed the core of the first Eucharist to be confessed and repeatedly recited by the Coptic faithful in the ancient churches of the whole Nile basin. The liturgy attributed to Mark constitutes the earliest form of Eucharistic offices in Africa and one of the earliest in the world ... African based liturgies still heard today are derived from that ascribed to St. Mark. (p. 246)
\end{abstract}

\section{Mark's martyrdom}

Peter and Paul were martyred in Rome (cf. Clement of Rome, To the Corinthians ca. 96; Hist. Eccl. 2.25; Tertullian, Praescr. 36), while Mark was martyred in Alexandria (Oden 2011a:128129). Oden (2011a:130) estimated the death of Peter to be between the middle of 64 and the beginning of 68 . Mark was most likely with Peter at that time. Eusebius (Chronicle) said that Peter and Paul died in 67-68 (Oden 2011a:130), but then also stated that Mark already died in the eighth year of Nero, that would be in $62 \mathrm{CE}$, making it impossible for him to be with Peter two or more years later.

Oden (2011a:151) depicted John Mark as the 'African prototype of both flight from persecution and martyrdom, which was so widely emulated elsewhere'. After Mark's last visit to the Pentapolis, he returned to Alexandria. As word spread, the unbelievers were immediately looking for him, but could not find him. He was well known for his miracles (Oden 2011a:152). At that moment of time there were three feasts in Alexandria (Oden 2011a:153):
- A pagan festival of Serapis

- The Christian celebration of the resurrection of Christ (Easter)

- The Paschal season among the Jews in Rhakotis.

Near the Serapeum in Rhakotis was a church (a house church - Oden 2011a:154) where the believers met (Oden 2011a:153). As Mark was preaching there, the mob found him. They forced their way into the congregation and seized Mark (Oden 2011a:154), immediately putting a rope around his neck, and then shouted: 'Drag the boubalos (buffalo) into the fields of Boukolou [Bucalis] where the cows graze' (Sawirus HP 146; Martyrium Marci 7; Oden 2011a:154). They then dragged him to Bucalis with horses, while he praised God (Oden 2011a:154). There they threw him into prison as he was not dead (Oden 2011a:156). Then followed an earthquake (Sawirus HP 146; Oden 2011a:156). During the night Mark received two alleged visits: Firstly, an angelic messenger came and comforted him (Martyrium Marci 8; Oden 2011a:156), and then Jesus himself appeared to him and comforted him (Oden 2011a:157). The next day, while they dragged Mark back to the Serapeum, he died giving his spirit to God (Sawirus HP 147; Oden 2011a:157). The mob then decided to burn him on a pyre at Angelion, but it suddenly started to rain and the wind blew strongly (Oden 2011a:157). As they beheld what was happening, many people died that day of fear and terror (Oden 2011a:157158). The believers then moved in, took the body and secretly buried him in Bucalis in a rock in the eastern side of the city (Sawirus HP 147-148; Oden 2011a:158). This happened in circa 68 (Oden 2011a:160). That burial site was the same site called Bucalis (Boukolos - the Jewish quarter near the shore; Oden 2011a:153) where Mark met Anianus (Oden 2011a:158).

Two interesting facts:

- In 311 Bishop Peter of Alexandria, also called Peter the martyr (the last martyr before Constantine), was beheaded at the Tomb of St Mark at Boukolou (Oden 2011a:159, 165).

- In 828 only Mark's head remained at the Angelion, while his body was stolen by Venetians.

\section{Oden's exposure of the West}

Oden sees Mark as the 'ecumenical beginning point for bringing together diverse Christian viewpoints of African Christianity' (Oden 2011a:29). His mission and passion was for the Gentiles (Mk 7:3-4, 31; cf. Oden 2011a:49). Mark became the patriarch of the whole family of African Christianity. He was Africa's first evangelist, apostle and martyr (Oden 2011a:52). He came from and returned to Africa. He was in Palestine at the crucial time of Jesus' death and resurrection. He then served in the early Christian mission that contributed to the primitive formation of the civilization of Europe (Oden 2011a:53). Oden pictured Mark as a Cyrenian Christian teacher, evangelist and prophet already tested in Antioch (Oden 2011a:136). 
The conclusion of his book forms a pinnacle to the whole argument of Oden, where he challenges the West to prove him wrong. He admits that he does not build his arguments on facts, but then the challenge (Oden 2011a):

If skeptics are determined to narrow down authentic Christianity only to that which can be indisputable proven by restrictive modern methods of assessing evidence, whom do they finally have as an audience? Well, first of all, not the church in Africa. Their largest potential audience is a tiny cluster of professional academics in the modern secular university. (pp. 255-256)

According to Oden (2011a:254), the two things the West keeps forgetting or tries to ignore are:

- the fact that African Christianity is the seedbed of Western culture.

- the fact that Africa was the source of great intellectual and spiritual wealth for the whole world.

The textbooks of the West regard the African memory to be a legend, 'an unreliable hagiographical oral tradition' (Oden 2011a:232). According to the viewpoint of the West, Mark was a Palestinian (Oden 2011a:23). The present Western assumption is that no evidence exists of a Libyan Christianity before the 3rd century and of an Egyptian one before the 2nd century (Oden 2011a:235). Through the years claims like these caused that Africa did not claim many of its own African-born sons and daughters (Oden 2011a:31). Examples are Pachomius, who contributed so much to the history of prayer and the life of holy living, Perpetua who witnessed till her death, Synesius who was born in Libya, and Monica who was born in Numidia.

Oden refers to Western historical criticism that appeared as a recent arrival in the history of interpretation of sacred texts, and is less than two centuries old (Oden 2011a:32). He has the view that this creates an unnecessary tension between a 2 000-year-old memory and a 200-year-old method of enquiry. He regards Walter Bauer as the one who has decisively affected the late-modern phase of historical studies of early Egyptian Christianity, because he called the Coptic memory into question (Oden 2011a:35), relying heavily on an 'argument from silence' - an argument that depends on what is not said, not what is said. He then challenges them to apply the same rule to other figures whose names we know but about whom we know nothing else in detail' (Oden 2011a:235) like the Hittite and Pharaonic kings, Buddha or Pythagoras.

Oden criticises the Western Christians further by saying that it is difficult for them to listen to a non-Western account, especially for those who are long-habituated to appeal first to historical-critical arguments. They are so prejudiced that they are prune to dismiss a story even before they listen to it. This kind of thinking prematurely rules out the traditional sources early African Christianity has at its disposal, even before the story has been told (Oden 2011a:53). The Western mindset goes so far as to rule Mark out as an eyewitness (Oden 2011a:75-76).
All these influences are actually dividing Christians in Africa. These influences are filled with Protestant suspicions and stereotypes that Coptic liturgy is out of date or even phony (Oden 2011a:29), that there were longstanding conflicts since the 5th century between Catholics and Copts, and that Coptic pride hesitated to concede any measure of apostolic authorisation to either Protestants or Catholics (Oden 2011a:29).

Von Harnack ([1902] 1962:xii), a good example of the Western mindset, discarded the African memory of Mark with these words:

The worthless character of this history is now recognised ... Whatever item from the apocryphal Acts, the local and provincial legends of the church, the episcopal lists, and the Acts of the martyrs, has not been inserted or noticed in these pages, has been deliberately omitted as useless. (cf. Oden 2011a:183-184)

Bauer concurred with Von Harnack as cited by Oden: Bauer condescendingly wonders in amazement 'why they [the Alexandrian tradition] should be content with a figure of the second rank [Mark] instead of choosing someone else from the illustrious band of Jesus' closest friends' (Bauer 1934; Oden 2011a:184). Walter Völker (1935) criticised Bauer by stating that Bauer arrived at his conclusions:

by frequent use from the argument from silence, by bold combinations, by unsupportable conjectures which themselves are reused as a precarious foundation for further conjectures, by inference drawn from later periods... I cannot believe that such a construction of history has prospects of becoming accepted. (cf. Oden 2011a:184)

The books and manuscripts of Mark have been preserved from 68 to Clement's time (Oden 2011a:204). This evidence helps scholars to understand the bridge of information between Mark and Eusebius. Eusebius accounts for the lacuna of documents about Mark in Alexandria spanning the years between 68 and 320 CE. It is this lacuna upon which liberal German historical scholarship since Von Harnack has depended so heavily, and judged so harshly (Oden 2011a:205). Africans have concluded ... that if a document comes from northern climes they have been found interesting for Western academic speculation. But if a document comes from Africa 'well, let's not rush to conclusions' (Oden 2011a:175).

Against the Westerners who say that Mark never even visited Alexandria (Oden 2011a:165), Oden's research indicated that the earliest church locations in Alexandria were intentionally identified by and named after events specifically connected with Mark's name and history (Oden 2011a:165). Leading sceptics on the death of Mark in Alexandria are Adolf Von Harnack, Walter Bauer and Hans Lietzmann (Oden 2011a:166).

Oden (2011a:234) has advice for the West: 'The validation of the African memory of Mark is best seen as a mosaic of fine points viewed as a pattern of circumstantial evidence. Only then will it come to have the plausibility for Westerners that it has enjoyed for twenty centuries among Africans.' 


\section{My adumbrations Layout of the book: Repetition}

Right through the book the author repeats himself smartly, most of the time adding information to what has already been said, especially in the first part of the book. For example, in chapter 1 he tells the story of Mark, just to repeat himself (with elaborations) in chapter 3 . However, this is in accordance with the way stories were told during these days. Even in the Bible we read how stories are duplicated, because they had different sources - take Genesis 1 and Genesis 2 as examples (two different creation stories) and the four Gospels, to name but two of these.

\section{Subjectivity and incisiveness}

Oden is very subjective, sometimes almost naive, when it comes to Africa. Notwithstanding these, he also shows a very cautious side on assuming information. Sometimes he is very sharp (in a negative way) in his critique of scholars who are not holding the same view as his. Oden, for example, refers to scholars who have the opinion that the Letter to Theodore did not originate with Clement: 'Most of the controversy over the letter has been engendered not by theological historians but by New Testament scholars. Some have shown eagerness to make their mark either by supposedly discovering alternative texts of Mark or by derogating such discoveries' (Oden 2011a:203). He also states (Oden 2011a):

But the standard trend of modern scholarship has been either to ignore or to discredit the whole lot of attestors to an African Mark, whether it be Papias or Eusebius or Clement, or more recently Smith. It makes us wonder: Where will such skepticism end except in doubting all sources altogether - the hermeneutics of suspicion on steroids - which finally brings all historical inquiry to a slow halt. (p. 210)

At some point Oden (2011a) lashes back at those who do not believe the African memory:

Is it possible that the death of Mark could have been invented out of phantasm or manufactured by mythmakers centuries later? To me it appears more likely that the mythmakers are those of nineteenth-century historicism. It is demeaning to the original confessors to assume that these pilgrimage sites are bogus ... Those who reject the gravitas of this historical consent fail to make an alternative case convincingly. To do so, they must find some way of countering the weight of historic ecumenical consent. This has not happened. (pp. 172-173)

\section{The Holy Spirit}

Oden refers to the Holy Spirit as if the early church was very familiar with the Third Person of the Holy Trinity. However, this was not the case. Origen was in fact the 'founder' of the Holy Spirit. Oden himself refers to Origen (First Principles preface) when he states that all Christian testimony and experience stands in this Spirit-led succession (Oden 2011a:57). Oden thus gives the impression that he is referring to all the witnesses of the early church, which is not true.
He states that, by the end of the 1st century, the Holy Spirit had led the apostolic witnesses to have included at least the four Gospels and the Pauline letters in their canon. He then says (Oden 2011a:57-58) that Mark and Luke-Acts, which are most crucial for the African memory of the identity of Mark, were likely written and received consensually as inspired Word by the time of the earliest apologists (Ignatius, Justin and Irenaeus). The question here is why he did not mention Clement of Alexandria in the same breath, as Clement also lived during that time and was more noted as apologist than the other church fathers.

\section{An apologetic touch}

Sometimes Oden tends to become apologetic about Africa. He argues, for example: 'If Peter could go as far as Rome and Paul could have the intent to go as far as Spain, why couldn't Mark go as far as Africa? ... All the world could never have excluded the great continent of Africa' (Oden 2011a:137). Another example:

The dangling question: If there are so many sites in Alexandria that recall Mark, his ministry, his arrest, his death, his attempted burning and his burial, why are they there in Alexandria if he never was in Alexandria? ... What accounts for the antiquity and persistence of martyr sites that correspond to the literary records, if they were mere fantasy?' (Oden 2011a:164-165)

Also, in referring to biblical and other references to Mark (Oden 2011a:219-221), he asks:

Given these mostly known facts and added references, why would it not be consistent with all of the above to consider it plausible that Mark might have also been sent under Peter's direction, to Alexandria, the second largest city in the Empire? (Oden 2011a:221)

\section{The Catechetical School}

As Oden is the one that really puts emphasis on the African memory, relying heavily on the ancient sources, he does not really do so with Mark's connection to the Catechetical School in Alexandria. Although great Coptic proponents like Malaty (1995) and Pope Shenouda III regard Mark as the founder of the School, Oden seems to ignore it. Shenouda III (cf. Oden 2011a:24) states that the three accomplishments of Mark were his Gospel, his Liturgy and the establishment of the Theological School in Alexandria, while Malaty (1995:208) postulated that the School was established by Mark in the early part of the 5th decade CE. Oden feels that Mark's contribution was that of 'the planting of the original idea for the Catechetical School of Alexandria' (Oden 2011a:241), although he mentions on the same page that preaching and teaching were Mark's central purposes. A few pages later he says that Mark is popularly remembered as 'honorary founder' of the School in Alexandria (Oden 2011a:245).

Oden (2011a:243) states that Eusebius 'carefully reported' the succession of key names of leadership in the School. This is not true, as Eusebius did not have the intention to do so. Philip Sidetes, a 5th-century historian of the early Christian 
church, did that in his Historia Ecclesiastica, described by Van den Broek (1996:199) as a 'voluminous but chaotic Christian History', consisting of twenty-four volumes, of which only fragments remained.

\section{Apollos}

To my mind there is one person who deserves more recognition from Oden, namely Apollos. Oden does not want to refer to Apollos as one who proclaimed the gospel in Alexandria before Mark. He refers to Apollos as follows (Oden 2011a):

He [Mark] had conceivably heard of the community ['protoChristians' according to Oden 2011a:214] that had taught Apollos ... Though not yet enjoying the fullness of Christian teaching or the work of the Holy Spirit, some in Alexandria were already in a state of readiness to hear the gospel. (pp. 142, 214)

Also when Mark arrived in Alexandria, he met Anianus who admitted to him: 'We mention God with our mouths, but that is all; for we know not who he is' (Sawirus HP 143; Oden 2011a:145).

Oden refers to Luke who says that Apollos was a 'learned man' from Alexandria with a 'thorough knowledge of Scripture' (Oden 2011a:142), but he feels that this refers only to the Torah and the Prophets. He says further (from the mouth of Luke) that Apollos was 'instructed in the way of the Lord, and spoke with great fervor and taught about Jesus accurately, though he knew only the baptism of John (Ac. 18:24)'. He concludes that Apollos was a native of Alexandria and that he had been taught the Hebrew Scriptures in his native country. He classifies Apollos as a messianic Jew (Oden 2011a:143), and admits that Apollos was a co-worker of Paul in Ephesus and Corinth who provided a glimpse into what was going on among Alexandrian Jews probably in the 40 s or 50 s. But just as one thinks he has to admit that Apollos proclaimed Christianity to Alexandria, he says the following: 'Does this mean that by the late 40s, there were proto-Christians in Alexandria? Unlikely, but there almost certainly were Jewish messianic believers who apparently had received some word concerning Jesus that was sufficient to prompt them to go all the way to Ephesus to witness.' Koester (2000:122) says that the mission of Apollos to Ephesus may even predate Paul's mission there (cf. also Oden 2011a:143). Oden, however, is so zoomed in on Mark that he does not want Apollos to steal the limelight in Alexandria.

\section{Oral culture}

In his critique on the West Oden states they are missing the point that '[i]t is self-evident that all written traditions were oral traditions before they were written' (Oden 2011a:233). In the last part of his book he states: 'If you take away orality from traditional African religion, you take away its beating heart' (Oden 2011a:237). On the same page he then elaborates on it: 'The story gives the facts a context. The story cannot be reduced to external evidence, since it is self-evidencing. In classic Christian doctrine, God the Spirit awakens the perception of the truth in the icon.' On the next page he articulates the following:

Speculations based on supposed or probable oral traditions are rife, endemic and ubiquitous within modern historical scholarship. This is particularly the case in the post-Bultmannian decades of the study of the New Testament ... I am appealing to neglected African oral and written traditions using their own methods. (Oden 2011a:238)

A remark that Oden makes, holds the heart of orality: He says that, even if the oral tradition of Mark would be proven completely false, 'even then none of the skeptics could successfully deny that it has shaped the spirit of African Christianity for two thousand years' (Oden 2011a:238).

\section{General points}

Oden's book does not contain many spelling errors. Apart from the difference in spelling between American and South African English, the following errors could be picked up (with the page number in brackets behind the error): 'Sawrius' (p. 66), 'it is was' (p. 71), 'a intermingling of gifts' (p. 85), 'cobler' (p. 144), 'Rakotis' (map p. 155), 'Pantaneus' (p. 195), 'Catechetical School' spelled inconsistently, sometimes with caps, sometimes no caps (caps on pages 198, 208, 241, 243 [twice] and 244), 'One persistent feature of the Mark's presence' (p. 219), 'Pythagorus' (p. 235) and 'Anyone can test this out by going go to a well-fitted university' (unknown construction for me; p. 235).

In his list of abbreviations he refers to PL as Patrologia Latina, but not to PG as Patrologia Graeca, while he refers to PG in two footnotes (pages 88 and 169). On page 212, with the reference to Acts 15:39, Oden states that Mark left Paul and Barnabas for Cyprus, while it should be Mark and Barnabas, leaving Paul for Cyprus.

\section{Conclusion}

There are quite a few scholars from Africa that are dedicated to doing research on and about this continent, like Jesse Mugambi, David Ngong, Kwame Bediako, Elizabeth Isichei and John Mbiti, to name but a few outstanding Africans, but not many Western scholars are keen on dedicating (the rest of) their life to enquiring the African mind. Thomas Oden, after his visit to the church of Augustine in Hippo in the 1970s, felt compelled to research the African memory, and he most definitely found more than he had bargained for. The trilogy of books, referred to in the introduction, is the proof and outcome of many years of extensive and thorough research done by a renowned scholar (of the West).

With his book, The African memory of Mark, Oden draws his reader into something most people have not or only heard of, but never experienced it themselves, and that is the African way of conveying stories or facts or 'facts'. He succeeds with acclamation with this book of his, notwithstanding minor shortfalls. 


\section{Acknowledgements Competing interests}

The author declares that he has no financial or personal relationships which may have inappropriately influenced him in writing this article.

\section{References}

Atiya, A.S., 1968, A history of Eastern Christianity, Methuen, London.

Bagnall, R.S., 1993, Egypt in Late Antiquity, Princeton University Press, Princeton, NJ.

Bagnall, R.S., 2001, 'Archaeological work on Hellenistic and Roman Egypt, 1995-2000', American Journal of Archaeology 105, 227-243.

Bauer, W., 1934, Orthodoxy and heresy in earliest Christianity, transl. R.E. Kraft, G. Krodel et al. (eds.), Fortress Press, Philadelphia, PA.

Brown, S.G., 2008, 'The Letter to Theodore: Stephen Carlson's case against Clement's authorship', Journal of Early Christian Studies 16(4), 535-572.

Carlson, S.C., 2005, The Gospel hoax: Morton Smith's invention of Secret Mark, Baylor University Press, Waco, TX.

Crossan, J.D., 1985, Four other gospels: Shadows on the contours of canon, Winston, Minneapolis, MN.

Crossan, J.D., 1988, The Cross that spoke: The origins of the Passion Narrative, Harpe $\&$ Row, San Francisco, CA.

Crossan, J.D., 1990, 'Thoughts on two extracanonical gospels', Semeia 49, 155-168.

Crossan, J.D., 1991, The historical Jesus: The life of a Mediterranean Jewish peasant, Harper, San Francisco, CA.

Doergen, H., 1937, 'Eusebius von Caesarea, der Vater der Kirchengeshichte', Theologie und Glaube 29, 446-448.

Encyclopedia Coptica, 2006, 'The Christian Coptic Orthodox Church of Egypt', viewed 08 February 2016, from http://www.coptic.net/EncyclopediaCoptica/

Girgis, S.F., 2002, A chronology of Saint Mark, St. John the Beloved Publishing House, Cairo.

Hanna, J., transl., 1875, Office of the Holy Communion according to the usage of the Coptic Church in Egypt, from the Divine Liturgy of St. Mark the Evangelist, transl. from text of J. Whittaker, T. Whittaker, New York.

History of Jerusalem, n.d., Booklet published by the See of Jerusalem (cf. Oden 2011a:99).

Hurtado, L.W., 2004, 'P45 and the textual history of the Gospel of Mark', in C. Horton (ed.), The earliest gospels, the origins and transmission of the earliest Christian gospels, the contribution of the Chester Beatty Gospel Codex P45, pp. 132-148, Journal for the Study of the New Testament, suppl., vol. 30, T\&T Clark International, London.

Jay, J., 2008, 'A new look at the epistolary framework of the Secret Gospel of Mark', Journal of Early Christian Studies 16(4), 573-597.

Koester, H., 1983, 'History and development of Mark's Gospel (From Mark to Secre Mark and "canonical" Mark)', in B.C. Corley (ed.), Colloquy on New Testament studies: A time for reappraisal and fresh approaches, pp. 35-57, Mercer University Press, Macon, GA.

Koester, H., 1990, Ancient Christian gospels: Their history and development, SCM Press, London; Trinity Press International, Philadelphia, PA.

Koester, H., 2000, Introduction to the New Testament: History and literature of early Christianity, vol. 2, 2nd edn., Walter de Gruyter, New York.

MacRory, J., 1910, 'Gospel of Saint Mark', in The Catholic Encyclopedia, vol. 9, viewed 03 February 2016, from http://www.newadvent.org/cathen/09674b.htm
Malaty, T.Y., 1995, Lectures in Patrology: The School of Alexandria. Book one: Before Origen, St. Mark's Coptic Orthodox Church, Jersey City, NJ.

Oden, T.C., 2007, How Africa shaped the Christian mind: The African seedbed of Western Christianity, InterVarsityPress, Downers Grove, IL.

Oden, T.C., 2011a, The African memory of Mark: Reassessing early church tradition, InterVarsityPress, Downers Grove, IL.

Oden, T.C., 2011b, Early Libyan Christianity: Uncovering a North African tradition, InterVarsityPress, Downers Grove, IL.

O'Neill, J., n.d., 'What does a black flag with a lion on it mean?' viewed 28 January 2016 from https://www.quora.com/What-does-a-black-flag-with-a-lion-on-it-mean

Paananen, T.S., 2012, 'From stalemate to deadlock: Clement's Letter to Theodore in recent scholarship', Currents in Biblical Research 11(1), 87-125.

Pearson, B.A., 1986a, 'Christians and Jews in first-century Alexandria', Harvard Theological Review 79(1-3), 206-216.

Pearson, B.A., 1986b, 'Earliest Christianity in Egypt: Some observations', in B.A Pearson \& J.E. Goehring (eds.), The roots of Egyptian Christianity, pp. 132-160, Westminster Press, Philadelphia, PA.

Pearson, B.A., 1990, Gnosticism, Judaism, and Egyptian Christianity: Studies in Antiquity \& Christianity, Fortress Press, Minneapolis, MN.

Pearson, B.A., 1991, 'Pre-Valentinian Gnosticism in Alexandria', in B.A. Pearson (ed.) The future of early Christianity: Essays in honour of Helmut Koester, pp. 132-157, Fortress Press, Minneapolis, MN.

Pearson, B.A., 1997, The emergence of the Christian religion: Essays on early Christianity, Trinity Press International, Harrisburg, PA.

Pearson, B.A., 2004, Gnosticism and Christianity in Roman and Coptic Egypt, T\&T Clark International, New York.

Roberts, C.H., 1979, Manuscript, society, and belief in early Christian Egypt, Oxford University Press, London, New York.

Robinson, J.H. (ed.), 1996, The Nag Hammadi Library in English, 4th rev. edn., Brill, Leiden.

Schenke, H-M. 1984, 'The mystery of the Gospel of Mark', Second Century 4, 65-82.

Schröter, J., 2010, 'The Gospel of Mark', in D.E. Aune (ed.), The Blackwell Companion to the New Testament, pp. 272-295. Wiley-Blackwell, Oxford.

Shenouda III, H.H., Pope, 1995, The beholder of God: Mark the evangelist, saint and martyr, transl. S.F. Mikhail \& M.S. Mikhail, 4th edn., St. Peter and St. Paul Coptic Orthodox Church, Santa Monica, CA.

Smith, R.M., 1973, The Secret Gospel: The discovery and interpretation of the Secret Gospel according to Mark, Harper \& Row, New York.

Smither, E.L., 2012, 'Thoughts on history, theology, culture', Criswell Theological Review 10(2), 91-93.

Theissen, G. \& Merz, A., 1996, The historical Jesus: A comprehensive guide, transl. J. Bowden, Fortress Press, Minneapolis, MN.

Van den Broek, R., 1996, Studies in Gnosticism and Alexandrian Christianity, Nag Hammadi and Manichaean Studies 39, E.J. Brill, Leiden.

Verdoner, M., 2014, 'The defenders of Christianity in the Ecclesiastical History of Eusebius', in D. Brakke, A-C. Jacobsen \& J. Ulrich (eds.), Early Christianity in the context of Antiquity, vol. 15: In defence of Christianity: Early Christian apologists, pp. 239-251, Peter Lang GmbH Europäischer Verlag der Wissenschaften, Frankfurt am Main.

Viklund, R. \& Paananen, T.S., 2013, 'Distortion of the scribal hand in the images of Clement's Letter to Theodore', Vigiliae Christianae 67, 235-247.

Völker, W., 1935, 'Review of Walter Bauer's Rechtgläubigkeit und Ketzerei im ältesten Christentum', Zeitschrift für Kirchengeschichte 54, 628-631.

Von Harnack, A., [1902] 1962, The mission and expansion of Christianity in the first three centuries, transl. James Moffat, Harper, New York.

Watson, F., 2010, 'Beyond suspicion: On the authorship of the Mar Saba Letter and the Secret Gospel of Mark', Journal of Theological Studies 61(1), 128-170. 